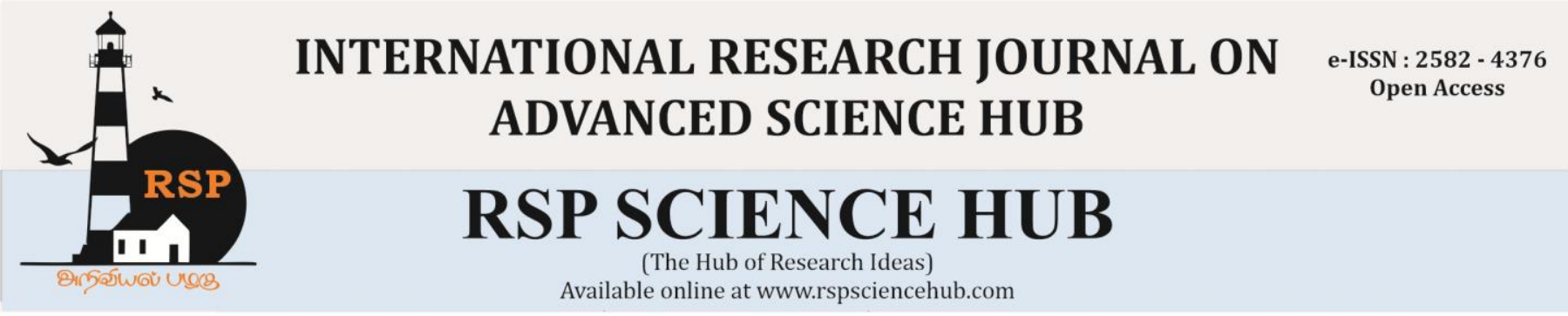

\title{
Comparative evaluation of effect of shielding gas using gas mixer and shielding gas alternator for GMAW of tube to tube joints
}

A. Santhakumari ${ }^{1}$, Dr. T. Senthilkumar ${ }^{2}$, Dr M chandrasekar ${ }^{3}$, N. Rajasekaran ${ }^{4}$

${ }^{1}$ Research Scholar, BIT Campus, Anna University, Tiruchy, India

${ }^{2}$ Dean \& Professor, BIT Campus, Anna University, Tiruchy, India

${ }^{3}$ Asst. Professor, BIT Campus, Anna University, Tiruchy, India

${ }^{4}$ Dy GM., BHEL, Tiruchirappalli, India

santhagct88@gmail.com ${ }^{1}$

\begin{abstract}
Gas Metal Arc Welding (GMAW) with alternating shielding gases is a method wherein two different shielding gases are alternatingly supplied to the torch for effectively protecting the weld pool from the atmospheric contamination. The alternating supply of two different shielding gases to the arc in GMAW produces an effect similar to pulsed current GMAW but dynamically more superior. GMAW with alternating shielding gases of argon and $\mathrm{CO}_{2}$ has been tried for welding of carbon and alloy steel tube butt joints. The properties of weldments with alternate shielding gas and conventional supply of shielding gases with mixing units have been evaluated. The arc experiences switching from globular transfer to short-circuiting within the weld puddle due to alternating shielding gases. This causes stirring in the molten weld pool and positively affects the weld pool thereby minimising spatter and porosity during welding. The bead characteristics of welds deposited with gas mixer have been compared to the characteristics obtained by welding with alternate shielding gas supply. The alternating supply of shielding gas in GMAW is found to consume less argon thereby provide significant cost savings in shielding gas.
\end{abstract}

Key Words: GMAW, Alternating shielding gas, Pulsed current GMAW, Argon, $\mathrm{CO}_{2}$

\section{INTRODUCTION}

Gas Metal Arc Welding process is employed widely in almost all industries for enhanced productivity and quality. For welding of ferrous based materials, a mixture of argon $+\mathrm{CO}_{2}$ is used as the shielding gas. Shielding gases are being used either as single or as a blend of two or more gases, according to the requirement. In addition to its shielding function, each gas or gas blend have unique physical properties that can have a major effect on penetration, mechanical properties, weld appearance and shape and arc stability. The current alternatives for the mixed gases is either using premixed gas cylinders or by using a gas mixer in the pre-determined ratio. For structural applications the ratio may be $80 \%$ Argon and $20 \%$ CO2. Form high temperature and high pressure applications, it may be in the range of 95:5 or even 98:2. The welding may be carried out in regular spray or pulsed spray mode. There is another alternative now available for improving the shielding effect by using alternate shielding gas technology by using gas alternator. 


\section{SHIELDING GAS ALTERNATOR}

The operating point in GMAW process depends on the shielding gas used; besides the wire feed speed [current] and voltage settings [1,2]. However, the stable operating point for each shielding gas viz. Argon and $\mathrm{CO}_{2}$ is located differently on the parametric window.

By use of alternating shielding gases wherein two different shielding gases are alternatingly supplied to the torch for effectively protecting the weld pool from the atmospheric contamination. The arc dynamics changes alternately in tune with the alternating shielding gas supply. The frequently changing arc dynamics positively influences the weld pool thereby the incidence of defects like porosity and crack are decreased.

Besides, it also results in improved weld metal mechanical properties in steel.Other factors such as flat bead profile and smooth weld metal transfer are considered to be beneficial aspects of gas pulsing in GMAW process. GMAW with alternating shielding gases is characterised by the switching of the transfer mode from spray to short circuiting type, which produces reliable fusion and penetration. Gas pulsing frequency and procedures have to be established to meet the quality requirements of tube butt joints.

The typical set up for GMAW process is shown in Fig. 1. Fig. 1 a shows the GMAW system with Gas Mixer.

As shown in Fig. 1b, in the gas alternator set up, two different input ( $\mathrm{Ar} \& \mathrm{CO}_{2}$ ) goes into the gas alternator and it gives the single output of the set required ratio $(0.1 \mathrm{sec}$ to $9 \mathrm{sec})$. The arc length, structure varies significantly during the switching of shielding gas from argon to carbon dioxide giving the molten weld pool a vigorous stirring effect.

From the schematic shown in Fig. 1c, it could be observed that the gas mixing unit is replaced with shielding gas alternator in place of gas mixer.

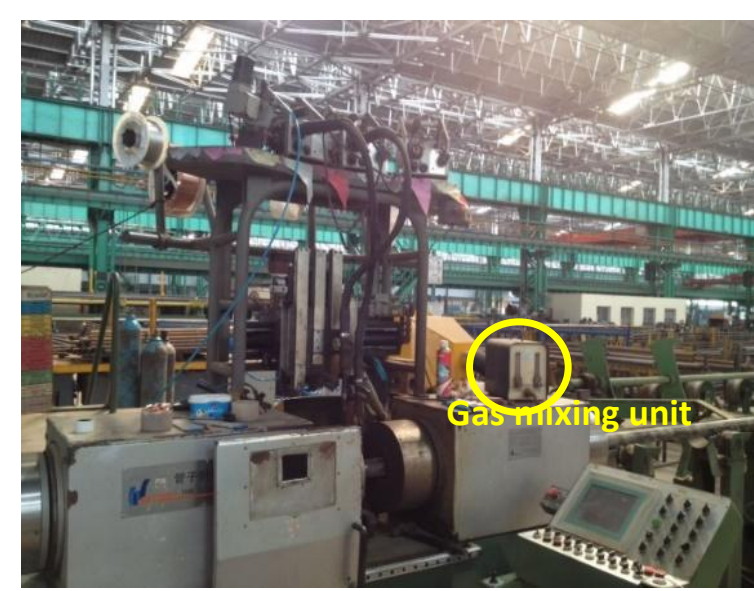

Fig. 1a GMAW with Gas mixing unit

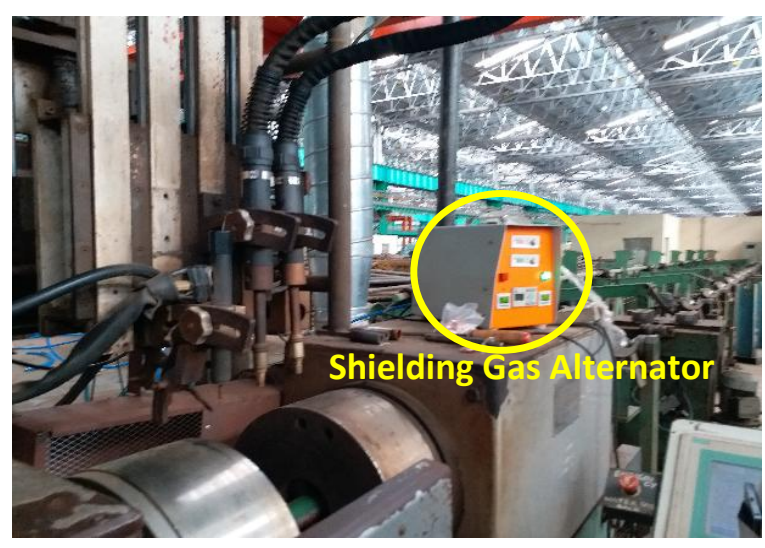

Fig. 1b GMAW with Shielding Gas Alternator

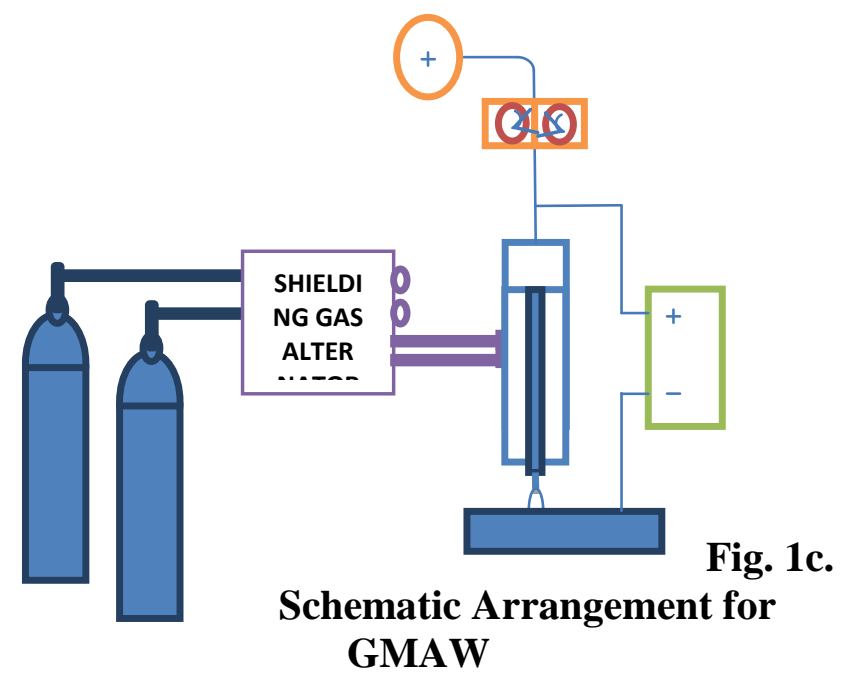

Fig. 1 Typical set up of GMAW 
www.rspsciencehub.com

3 INFLUENCES

ON

ARC

\section{CHARACTERISTICS}

As indicated earlier, periodically alternating the shielding gases between argon and $\mathrm{CO}_{2}$ significantly influences the arc characteristics. The current and voltage transients are captured to study the effect of alternating shielding gas effect on the arc. The current and voltage signatures are captured using the Analyser Hannover system. The current and voltage transient signatures are shown in Fig 2.

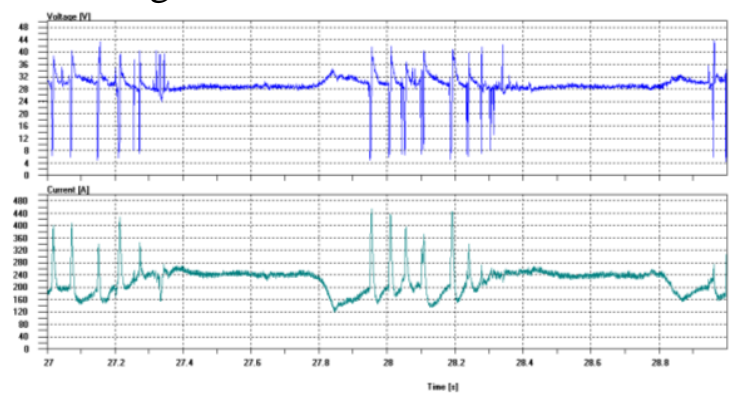

Fig 2. Current and voltage transients in GMAW under alternating shielding gases of $\operatorname{argon}(0.8 \mathrm{~s}) \& \mathrm{CO}_{2}(0.2 \mathrm{~s})$.

The smooth horizontal line segments in the current, voltage transient signature indicate the argon shielding phase where the arc is smooth with spray mode of transfer and the segments with spikes in the current, voltage transient signature indicate the $\mathrm{CO}_{2}$ shielding phases where arc changes to short circuiting mode. Nearly 8 to 10 short circuits occur within the span of 0.2 seconds. This superimposition of short duration short circuit transfers of $\mathrm{CO}_{2}$ in the regular spray transfer of argon creates a stirring effect on the weld pool which positively influences the process. The porosity level comes down significantly and microstructure of the weld also gets altered favourably.

\section{EXPERIMENTAL DETAILS}

GMAW with alternating shielding gas is a new technology. The integrity of this process has been evaluated through experiments.

Trials have been done at tube to tube joining machines on three different materials which are of conventionally used for high temperature high pressure applications. The following are the sample tube that have been taken up for study and the dimensions are given below.
Volume 02 Issue 07 July 2020

- ASTM SA2 $10 \mathrm{Gr}$ 'C' -Ø44.45mm*7.1mm

- ASTM SA213 T12 -Ø57.15mm*14.3mm

- ASTM SA213 T22 -Ø51mm*5.6mm

The materials have been edge prepared by the facility available and welding trials have been done with the conventional process of welding with gas mixing unit on the chosen material and with the alternator developed by WRI. The parameters which have used for the welding trials are tabulated in Tables $1 \& 2$.

\section{Table 1 Parameters for GMAW with Gas} Mixer

\begin{tabular}{|l|r|r|r|}
\hline Parameter & $\begin{array}{c}\text { SA 210 } \\
\text { Gr 'C' }\end{array}$ & $\begin{array}{c}\text { SA 213 T } \\
\mathbf{1 2}\end{array}$ & $\begin{array}{c}\text { SA } \\
\mathbf{2 1 3} \text { T } \\
\mathbf{2 2}\end{array}$ \\
\hline No of & 2 & 5 & 2 \\
passes & & & \\
\hline Welding & 95,94, & 95,94, & 93,92, \\
current (A) & 93 & 93,92, & 90 \\
& & 92,93 & \\
\hline Welding & 24.5, & 24,24, & 23.5, \\
voltage & 24,23 & $23,22.5$, & 23,22 \\
(V) & & $22,22.5$ & \\
\hline Weld & 280, & 240,120 & 320, \\
speed (mm & 130, & 100,80, & 200, \\
/ min) & 160 & 80,90 & 210 \\
\hline Oscillation & 50, & 30,2400, & 40, \\
speed (mm & 2400, & 2100, & 2600, \\
/ min) & 2600 & 1800, & 2700 \\
& & 1800, & \\
& & 1800 & \\
\hline Shielding & $\mathbf{9 5 \%}+$ & $\mathbf{9 5 \%}+$ & $\mathbf{9 5 \%}+$ \\
gas Ar + & $\mathbf{5 \%}$ & $\mathbf{5 \%}$ & $\mathbf{5 \%}$ \\
CO $\%$ & & & \\
\hline
\end{tabular}

Number of experiments done prior to set the frequency while using alternator. Preheating has been done as per requirement using LP gas before welding. After welding, the samples are subjected to PWHT also as per ASME code requirement.

Transverse tensile and impact specimens have been extracted from the welded tubes and tested as per AWS standard. Microstructural studies have been observed in the base metal and weld metal in different shielding gas conditions. 
Table 2 Parameters for GMAW with Gas Alternator

\begin{tabular}{|c|c|c|c|}
\hline Para & $\begin{array}{l}\text { SA } 210 \\
\text { Gr ' } C \text { ' }\end{array}$ & $\begin{array}{c}\text { SA } 213 \\
\text { T } 12\end{array}$ & $\begin{array}{c}\text { SA } 213 \\
\text { T } 22 \\
\end{array}$ \\
\hline ses & 2 & 5 & 2 \\
\hline $\begin{array}{l}\text { Welding } \\
\text { current (A) }\end{array}$ & $\begin{array}{r}94,93, \\
92\end{array}$ & $\begin{array}{c}94,95, \\
95,94, \\
96,95\end{array}$ & $\begin{array}{r}94,93, \\
92\end{array}$ \\
\hline $\begin{array}{l}\text { Welding } \\
\text { voltage } \\
\text { (V) }\end{array}$ & $\begin{array}{r}25,24, \\
22.5\end{array}$ & $\begin{array}{r}25,24 \\
24,24 \\
25,22.5\end{array}$ & $\begin{array}{r}24,24, \\
22\end{array}$ \\
\hline $\begin{array}{l}\text { Weld } \\
\text { speed (mm } \\
\text { / min) }\end{array}$ & $\begin{array}{r}290,150 \\
, 210\end{array}$ & $\begin{array}{r}270,120 \\
80,85 \\
80,90\end{array}$ & $\begin{array}{l}330, \\
200, \\
210\end{array}$ \\
\hline$(\mathrm{mm}$ & $\begin{array}{r}40,2600 \\
, 2600\end{array}$ & $\begin{array}{r}30,2000 \\
1800 \\
1600 \\
1500 \\
1600 \\
\end{array}$ & $\begin{array}{r}40, \\
2600, \\
2700\end{array}$ \\
\hline $\begin{array}{l}\text { Shielding } \\
\text { gas Ar + } \\
\mathrm{CO}_{2} \%\end{array}$ & $\begin{array}{l}\mathrm{Ar} \quad- \\
0.02 \mathrm{sec} \\
\mathrm{CO}_{2}- \\
0.04 \mathrm{Sec}^{2}\end{array}$ & $\begin{array}{l}\mathrm{Ar}- \\
0.02 \mathrm{sec} \\
\mathrm{CO}_{2}- \\
0.04 \mathrm{Sec}\end{array}$ & $\begin{array}{l}\mathrm{Ar}- \\
0.02 \text { s } \\
\mathrm{CO}_{2}- \\
\mathrm{O.04}_{\mathrm{s}}\end{array}$ \\
\hline
\end{tabular}

\section{RESULTS AND DISCUSSIONS}

The mechanical properties of welds deposited by GMAW with alternating supply of argon and $\mathrm{CO}_{2}$ shielding gases have been studied and compared with that of the weld metal deposited by GMAW with gas mixers.

\subsection{NDT-Real Time Radiography (RTR) Test}

The three varieties of steels (Grade C, T12 and T22) were welded were subjected to Radiography (RT) test to ensure the soundness of the joint.

\subsection{Tensile Test}

The tensile strength of the weld was determined by using UTM $600 \mathrm{kN}$. The transverse tensile test specimen is prepared as per the standard AWS B4.0.
Table 3 Tensile Results for SA 210 Gr. C Material

\begin{tabular}{|c|c|c|}
\hline \multirow[b]{2}{*}{ ID No. } & \multicolumn{2}{|c|}{ GAS MIXER } \\
\hline & $\begin{array}{c}\text { UTS } \\
\text { (MPa) }\end{array}$ & $\begin{array}{c}\text { Location of } \\
\text { failure }\end{array}$ \\
\hline $\mathrm{C} 1$ & 450 & Base Metal \\
\hline $\mathrm{C} 2$ & 435 & Base Metal \\
\hline $\mathrm{C} 3$ & 465 & Base Metal \\
\hline \multirow[b]{2}{*}{ ID No. } & \multicolumn{2}{|c|}{ GAS ALTERNATOR } \\
\hline & $\begin{array}{c}\text { UTS } \\
\text { (MPa) }\end{array}$ & $\begin{array}{c}\text { Location of } \\
\text { failure }\end{array}$ \\
\hline C-A32 & 460 & Base Metal \\
\hline C-A13 & 458 & Base Metal \\
\hline C-A31 & 457 & Base Metal \\
\hline
\end{tabular}

The transverse tensile test results for alternating supply of shielding gases (0.25 s Ar: $0.50 \mathrm{~s} \mathrm{CO}_{2}$ ) and gas mixing unit is presented in Fig. 3 and the results are tabulated in Table 3 for SA 210 Gr. C material.
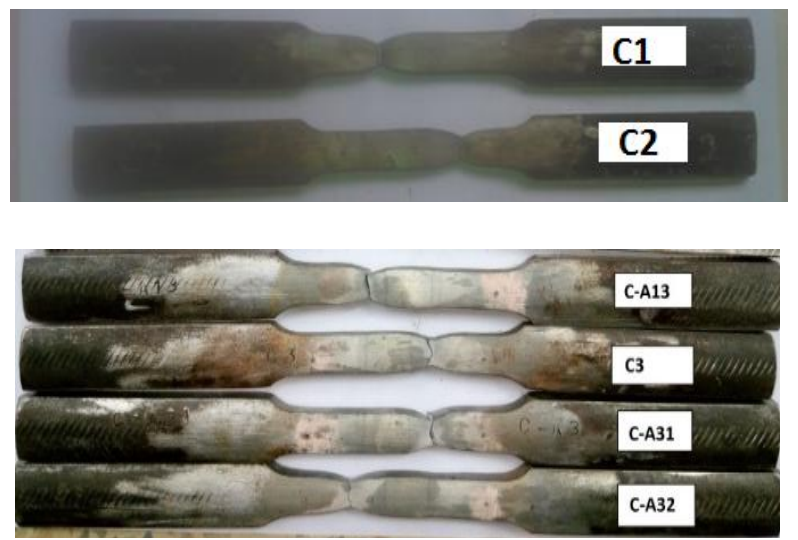

Fig. 3 SA 210 Gr. C Tensile Specimens After Testing

From Fig. 3, it can be seen that the fracture occurred in the base metal of both weld methods. So, the weld metal has better tensile strength than the base metal and meet the code requirements.

Table 4 shows the transverse tensile test results for SA 213 T12 tubes and Fig. 4 shows the specimens after testing.

From Fig. 4, it can be seen that the fracture occurred in the base metal of both weld methods. So, the weld metal has better tensile strength than the base metal and meet the code requirements. 
Table 4 Tensile Results for SA 213 T12 Tubes

\begin{tabular}{|c|r|c|}
\hline \multirow{2}{*}{ ID No. } & \multicolumn{2}{|c|}{ GAS MIXER } \\
\cline { 2 - 3 } & $\begin{array}{c}\text { UTS } \\
\text { (MPa) }\end{array}$ & $\begin{array}{c}\text { Location of } \\
\text { failure }\end{array}$ \\
\hline T22-C31 & 430 & Base Metal \\
\hline T22-C32 & 401 & Base Metal \\
\hline T22-C33 & 477 & Base Metal \\
\hline & \multicolumn{2}{|c|}{ GAS ALTERNATOR } \\
\hline ID No. & \multicolumn{1}{|c|}{$\begin{array}{c}\text { UTS } \\
\text { (MPa) }\end{array}$} & $\begin{array}{c}\text { Location of } \\
\text { failure }\end{array}$ \\
\hline A31 & 476 & Base Metal \\
\hline A42 & 423 & Base Metal \\
\hline A43 & 473 & Base Metal \\
\hline
\end{tabular}

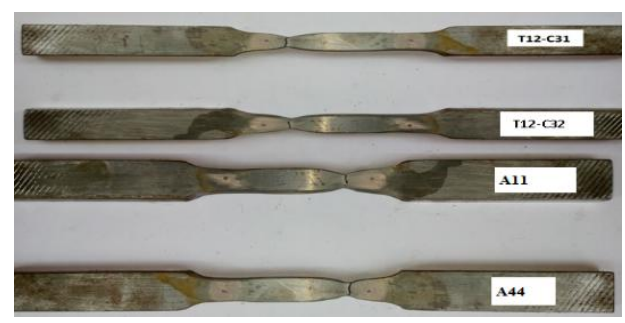

Fig. 4 SA 213 T12 Tensile Specimens After Testing

Table 5 Tensile Results for SA 213 T22 Tubes

\begin{tabular}{|c|r|c|}
\hline \multirow{2}{*}{ ID No. } & \multicolumn{2}{|c|}{ GAS MIXER } \\
\cline { 2 - 3 } & $\begin{array}{c}\text { UTS } \\
\text { (MPa) }\end{array}$ & $\begin{array}{c}\text { Location of } \\
\text { failure }\end{array}$ \\
\hline T12-C31 & 467 & Base Metal \\
\hline T12-C32 & 470 & Base Metal \\
\hline & GAS ALTERNATOR \\
\hline ID No. & $\begin{array}{c}\text { UTS } \\
\text { (MPa) }\end{array}$ & $\begin{array}{c}\text { Location of } \\
\text { failure }\end{array}$ \\
\hline A11 & 473 & Base Metal \\
\hline A44 & 463 & Base Metal \\
\hline
\end{tabular}

Table 5 shows the transverse tensile test results for SA 213 T22 tubes and Fig. 5 shows the specimens after testing.

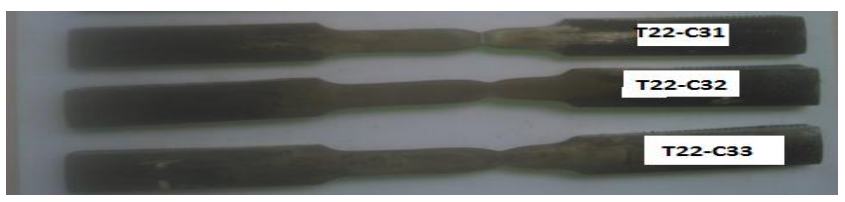

Fig. 5SA 213 T22Tensile Specimens After Testing

From Fig. 5, it can be seen that the fracture occurred in the T22 base metal of both weld methods. So, the weld metal has better tensile strength than the base metal and meet the code requirements.

\subsection{Bend Test}

The welds were subjected to guided bend tests and test coupons were prepared as per AWS B 4.0. Both transverse face and root bend tests(for Gr C \& T22 tubes and side bend test for T12 tubes) were carried out to evaluate both the ductility and soundness of the weldments. $180^{\circ}$ bend tests with mandrel diameter equal to $4 \mathrm{t}$ were carried out on all welded samples. All the three specifications were tested and the results are tabulated in Tables 6 to 8. The face and rootbend tested images are shown from Fig. 6 to Fig. 8 .

Table 6 Guided Bend Test Results for SA

\begin{tabular}{|c|c|c|c|c|c|}
\multicolumn{7}{|c|}{ G10 Gr C } \\
\hline $\begin{array}{c}\text { ID } \\
\text { No. }\end{array}$ & $\begin{array}{c}\text { Face } \\
\text { Bend }\end{array}$ & $\begin{array}{c}\text { Rema } \\
\text { rks }\end{array}$ & $\begin{array}{c}\text { ID } \\
\text { No. }\end{array}$ & $\begin{array}{c}\text { Root } \\
\text { Bend }\end{array}$ & $\begin{array}{c}\text { Remar } \\
\text { ks }\end{array}$ \\
\hline C4 & $\begin{array}{c}\text { No } \\
\text { open } \\
\text { disconti } \\
\text { nuity }\end{array}$ & Passed & C3 & $\begin{array}{c}\text { No } \\
\text { open } \\
\text { disco } \\
\text { ntinu } \\
\text { ity }\end{array}$ & Passed \\
\hline \multicolumn{7}{|c|}{ GAS ALTERNATOR } \\
\hline C- & $\begin{array}{c}\text { No } \\
\text { open } \\
\text { disconti } \\
\text { nuity }\end{array}$ & Passed & $\begin{array}{c}\text { C- } \\
\text { A15 }\end{array}$ & $\begin{array}{c}\text { No } \\
\text { open } \\
\text { disco } \\
\text { ntinu } \\
\text { ity }\end{array}$ & Passed \\
\hline
\end{tabular}



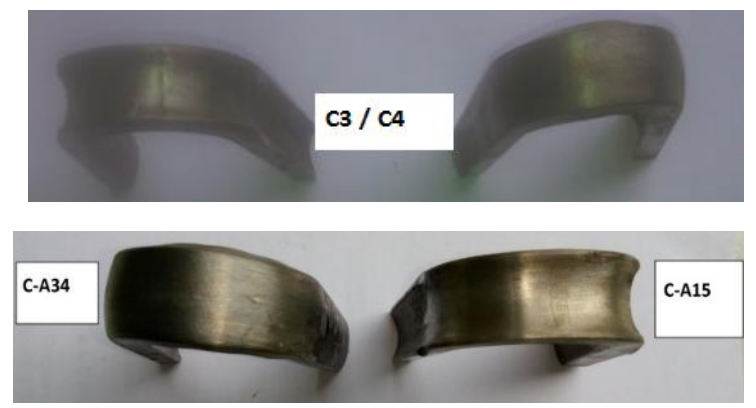

Fig. 6 SA 210 Gr C Specimens After Face \& Root Bend Testing

Table 7 Guided Bend Test Results for SA 213 T12

\begin{tabular}{|c|c|c|}
\hline \multicolumn{3}{|c|}{ GAS MIXER } \\
\hline ID No. & Side Bend & Remarks \\
\hline C41 & $\begin{array}{c}3.25 \text { mm Open } \\
\text { discontinuity }\end{array}$ & Failed \\
\hline \multicolumn{3}{|c|}{ GAS ALTERNATOR } \\
\hline A12 & $\begin{array}{c}\text { No open } \\
\text { discontinuity }\end{array}$ & Passed \\
\hline
\end{tabular}

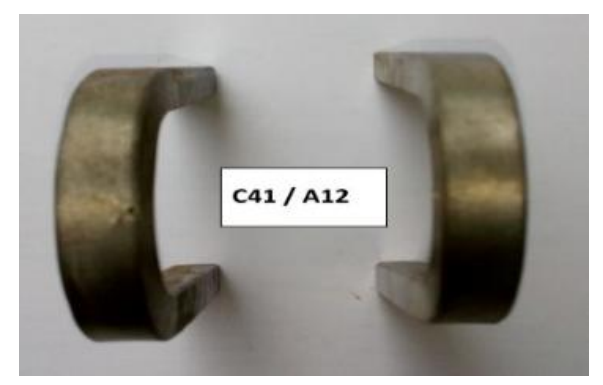

Fig. 7 SA 213 T12 Specimens After Face \& Root Bend Testing

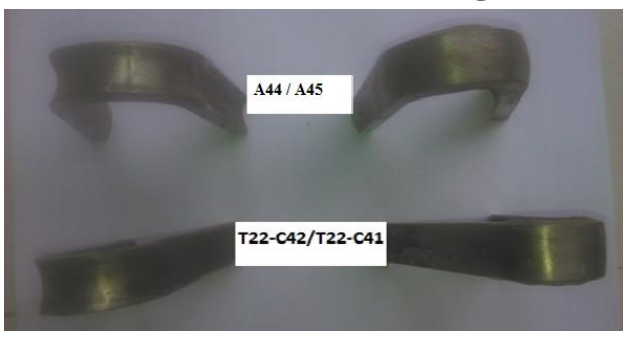

Fig. 8 SA 213 T22 Specimens After Face \& Root Bend Testing
Table 8 Guided Bend Test Results for SA 213 T22

\begin{tabular}{|c|c|c|c|c|c|}
\hline \multicolumn{6}{|c|}{ GAS MIXER } \\
\hline $\begin{array}{r}\text { ID } \\
\text { No. }\end{array}$ & $\begin{array}{l}\text { Face } \\
\text { Bend }\end{array}$ & $\begin{array}{l}\text { Re } \\
\text { ma } \\
\text { rks }\end{array}$ & $\begin{array}{r}\text { ID } \\
\text { No. }\end{array}$ & $\begin{array}{l}\text { Root } \\
\text { Bent }\end{array}$ & $\begin{array}{c}\text { Re } \\
\text { mar } \\
\text { ks } \\
\end{array}$ \\
\hline $\begin{array}{l}\text { T22- } \\
\mathrm{C} 41\end{array}$ & $\begin{array}{c}\text { No } \\
\text { open } \\
\text { disconti } \\
\text { nuity }\end{array}$ & $\begin{array}{l}\text { Pas } \\
\text { sed }\end{array}$ & $\begin{array}{c}\mathrm{T} 22 \\
- \\
\mathrm{C} 42\end{array}$ & $\begin{array}{c}\text { No } \\
\text { open } \\
\text { disconti } \\
\text { nuity }\end{array}$ & $\begin{array}{c}\text { Pass } \\
\text { ed }\end{array}$ \\
\hline \multicolumn{6}{|c|}{ GAS ALTERNATOR } \\
\hline A44 & $\begin{array}{c}\text { No } \\
\text { open } \\
\text { disconti } \\
\text { nuity }\end{array}$ & $\begin{array}{l}\text { Pas } \\
\text { sed }\end{array}$ & A 45 & $\begin{array}{c}\text { No } \\
\text { open } \\
\text { disconti } \\
\text { nuity }\end{array}$ & $\begin{array}{c}\text { Pass } \\
\text { ed }\end{array}$ \\
\hline
\end{tabular}

\subsection{Charpy V - Notch Impact Test}

To compare the toughness properties of both the weldments from T22 samples were subjected to Charpy V notch impact test. The impact test specimens were prepared as per the standard AWS B 4.0. The test results are tabulated in Table 9 and Fig. 9 shows the tested samples.

The average value for gas mixer is $70.67 \mathrm{~J}$ and for gas alternator is $96 \mathrm{~J}$. From the test values, it is evident that the weld metal deposited with alternating shielding gases GMAW has better toughness properties as compared to the weld metal deposited with gas mixer.

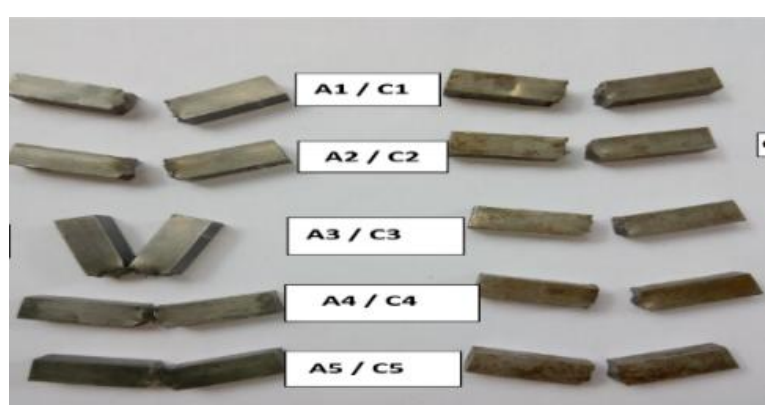

Fig. 9 Impact Specimens for SA 213 T22 Material after Testing 
HAZ is only $6.189 \mathrm{~mm}$ whereas the HAZ of the

Table 9 Impact Results for SA 213 T22 Material

\begin{tabular}{|c|r|c|r|}
\hline \multicolumn{2}{|c|}{ GAS MIXER } & \multicolumn{2}{c|}{ GAS } \\
\hline ID & Impact & ID & \multicolumn{1}{c|}{ Impact } \\
No. & Energy in J & No & Energy in J \\
\hline C1 & 72 & A1 & 90 \\
\hline C2 & 81 & A2 & 104 \\
\hline C3 & 44 & A3 & 106 \\
\hline C4 & 85 & A4 & 77 \\
\hline C5 & 59 & A5 & 94 \\
\hline Avg. & $\mathbf{7 0 . 6 7}$ & & $\mathbf{9 6}$ \\
\hline
\end{tabular}

\subsection{Heat Input}

The heat input per pass was calculated for for all the three materials based on the welding voltage, welding current and welding speed and compared for both types of welds made with gas mixer and gas alternator.

From Table 10, it can be seen that the heat input for the welds made with gas alternator is significantly lesser than that of welded with gas mixer. This also can be attributed for better mechanical properties and resulted in fine grain size.

\section{Table 10 Heat Input}

\begin{tabular}{|l|r|r|r|r|r|}
\hline \multirow{2}{*}{} & \multirow{2}{*}{ Volt } & \multirow{2}{*}{ Amp } & \multirow{2}{*}{ Speed } & \multicolumn{2}{|c|}{$\begin{array}{c}\text { Heat input rate } \\
\text { kJ mm }\end{array}$} \\
\cline { 4 - 7 } & & & & Mixer & Alternator \\
\hline \multirow{2}{*}{ Gr } & 23.83 & 94 & 190 & 0.707 & -- \\
\cline { 2 - 6 } C & 23.83 & 93 & 216 & -- & 0.615 \\
\hline \multirow{2}{*}{ T1 } & 23.91 & 93.5 & 115 & 1.167 & -- \\
\hline 2 & 24.08 & 94.83 & 120.83 & -- & 1.134 \\
\hline \multirow{2}{*}{ T2 } & 23.33 & 93 & 246.66 & 0.527 & -- \\
\cline { 2 - 6 } 2 & 22.83 & 91.67 & 243.33 & -- & 0.516 \\
\hline
\end{tabular}

\subsection{Effect on Heat Affected Zone (HAZ)}

Fig. 10to Fig. 12showthe macro of welds made with gas mixer and alternate shielding gas. Due to low heat input with the alternator the width of

gas mixer is 7.70 for SA 210 Gr. C (Fig. 10).

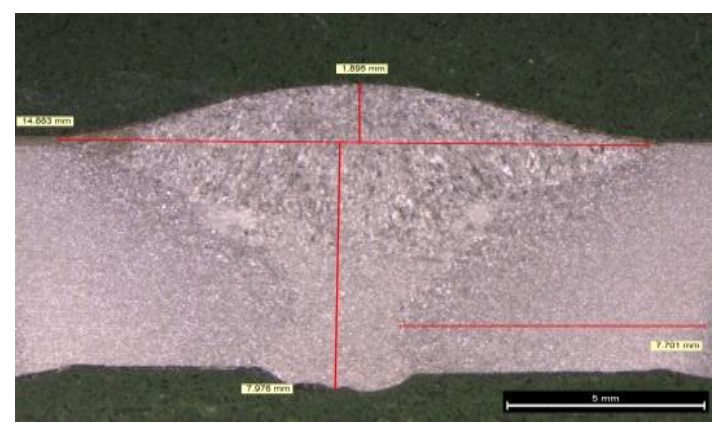

Fig. 10 a) gasmixer

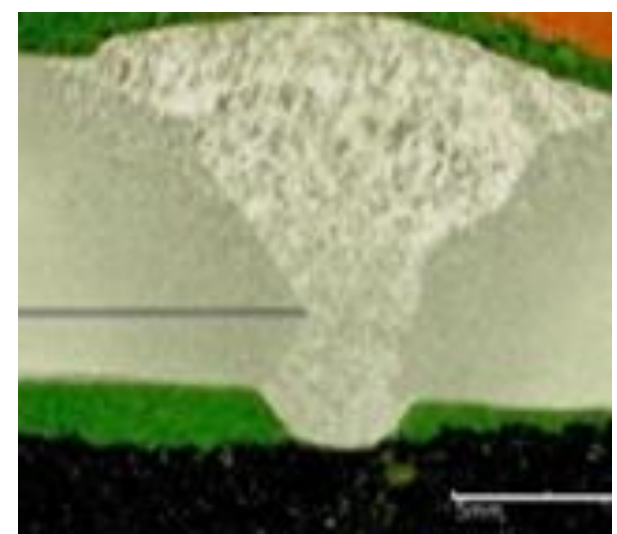

Fig. 10b) gas alternator

Fig. 10 Macrograph of SA 210 Gr C

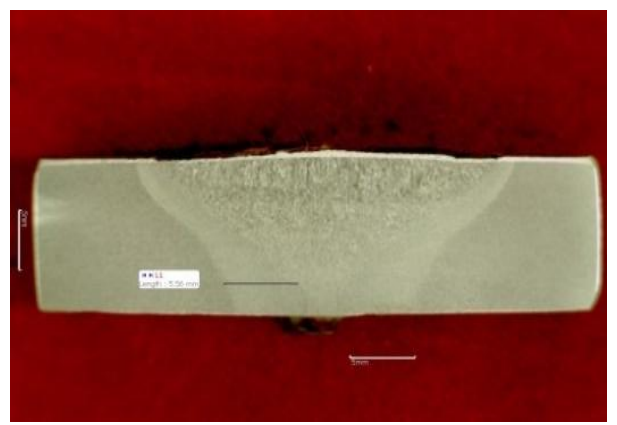

Fig. 11 a) gas mixer

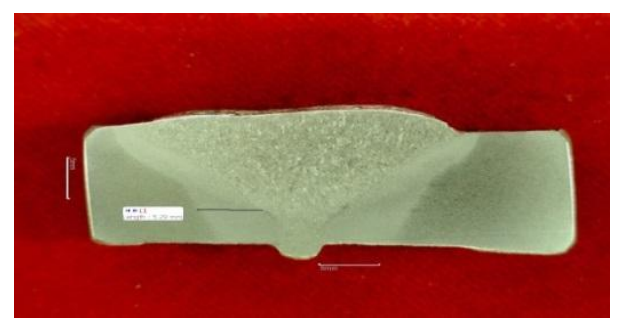

11 b) gas alternator

Fig. 11 Macrograph of SA 213 T12 


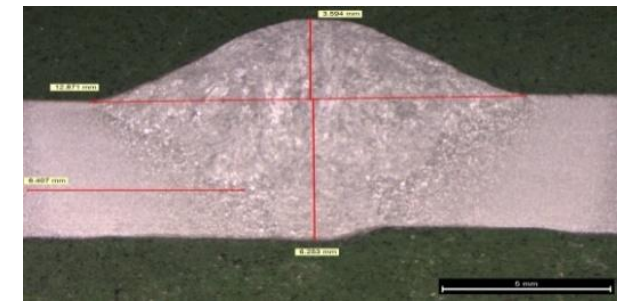

Fig. 12 a) gas mixer

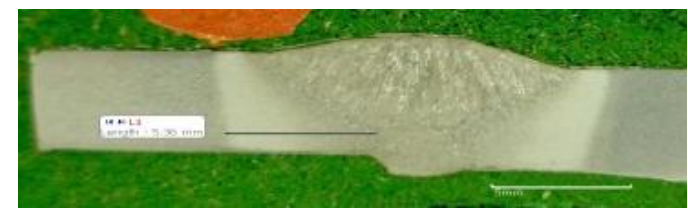

Fig. 12 b) gas alternator

Fig. 12 Macrograph of SA 213 T22

From Fig. 11 it could be observed that the width of HAZ is $5.29 \mathrm{~mm}$ is for the weld with gas alternator against $5.56 \mathrm{~mm}$ for SA $213 \mathrm{~T} 12$ gas mixer welds and this may be due to the low heat input in alternating shielding gas supply to the weld pool. For SA $213 \mathrm{~T} 22$, it is $6.407 \mathrm{~mm}$ for gas mixer and $5.36 \mathrm{~mm}$ for gas alternator for the same reasons, as shown in Fig. 12.

The improved tensile and toughness properties of the weld metal deposited with alternating shielding gases of argon and $\mathrm{CO}_{2}$ as compared to mixing unit is attributed to the fine grain size and improved microstructure. Grain size has a strong effect on transition temperature. An increase of one ASTM number in the ferrite grain size (a decrease in grain diameter) can result in a decrease in transition temperature [4]. Decreasing the grain diameter decrease the transition temperature and improve the impact resistance.

\subsection{Microstructure}

The microstructural study was done under the optical microscope under proper illumination condition in the desired region, under 500X magnification. The microstructure of the SA 210 Gr C base material shows the presence of ferrite and pearlite constituents as shown in Fig. 13.

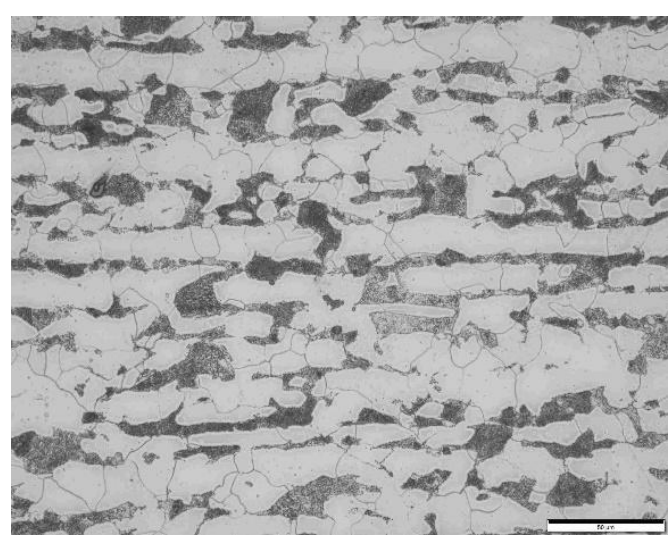

Fig. 13 base Material Gr C (500X)

\begin{tabular}{|c|c|}
\hline Gas Mixer & Gas Alternator \\
\hline & \\
& \\
& \\
& \\
& \\
\hline
\end{tabular}

Fig. 14.Microstructures of SA 210 Gr C with gas mixer and gas alternator $\mathrm{HAZ}$

The HAZ microstructure of SA 210 Gr. C welded with Gas Mixer and Gas Alternator in shown in Fig. 14. The micro structure consists of widmanstatten ferrite, bainite and grain boundary ferrite. Grain size are coarser in gas mixer whereas as the grain size are finer in gas alternator.

The weld metal microstructure of SA $210 \mathrm{Gr}$ C tubes made with Gas Mixer and Gas Alternator in shown in Fig. 15. The microstructure of weld metal contains mainly acicular ferrite, widmanstatten ferrite, grain boundary ferrite and bainite. Significant polygonal ferrite was observed along with acicular ferrite at the bottom of weld as seen in Fig 15 (e \& f). 


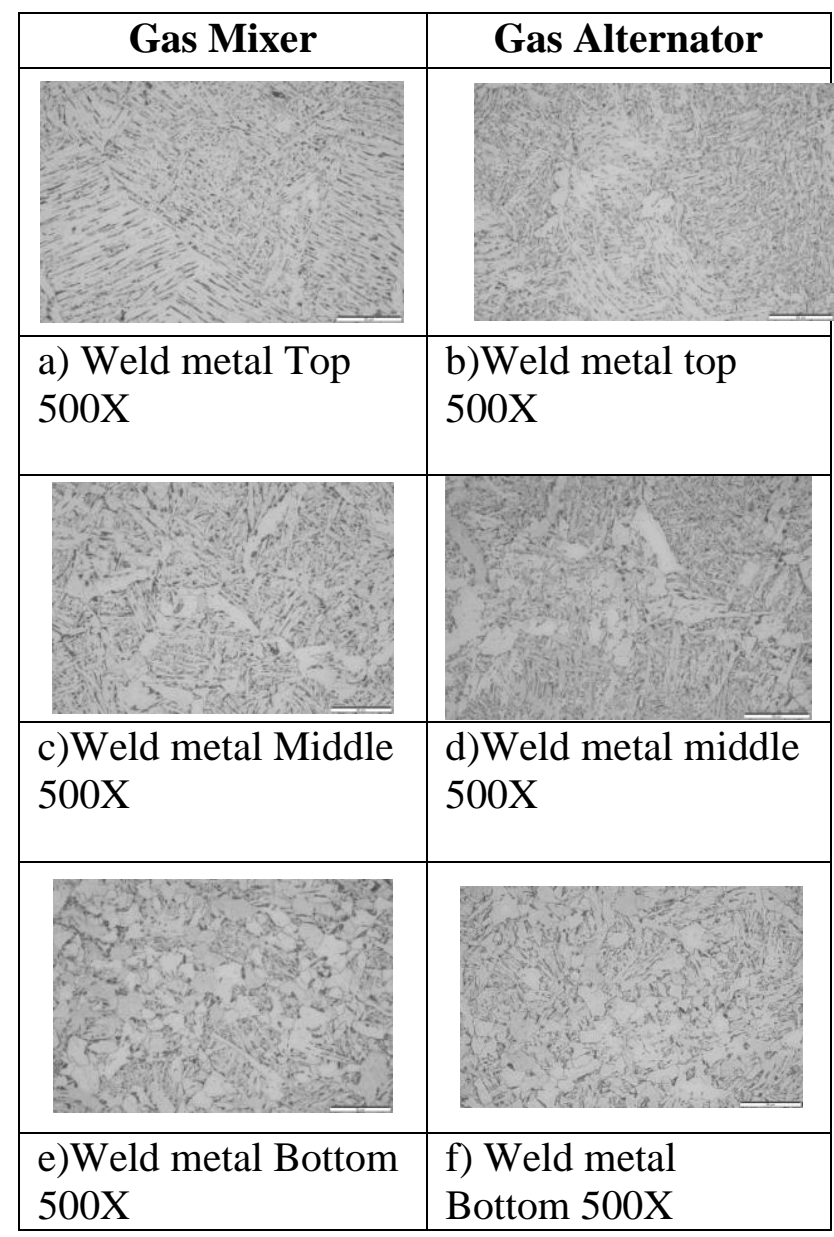

Fig. 15 Microstructures of SA 210 Gr C with gas mixer and gas alternator Weld metal

Similarly, the microstructure of base materials, HAZ and weld metal for SA 213 T12 tube are shown in Fig. 16 to Fig. 18, respectively.

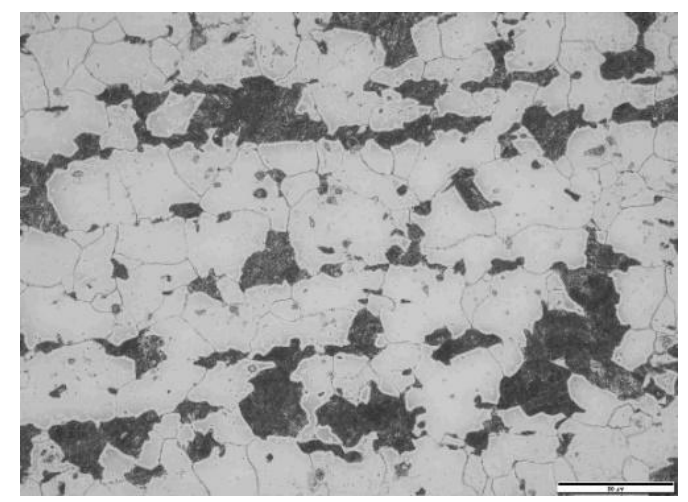

Fig. 16 SA 213 T12 Base Metal Microstructure 500X
Equal amount of polygonal ferrite and bainite was seen in base metal. Hard martensitic phase was observed at the HAZ; also prior austenite grain boundary is seen (Fig. 17).

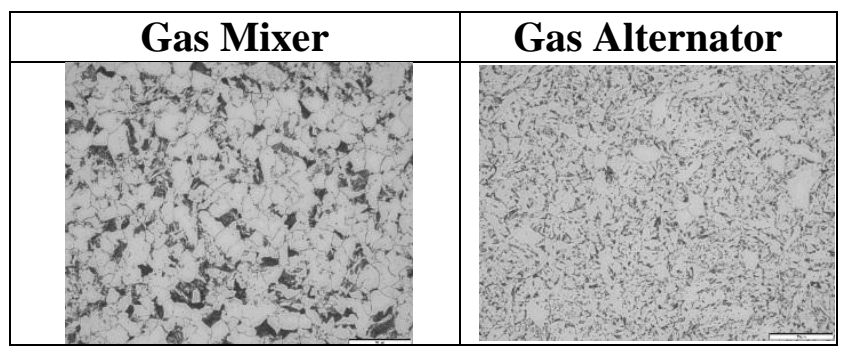

Fig. 17 Microstructures of SA 213 T12 with gas mixer and gas alternator $\mathrm{HAZ}$

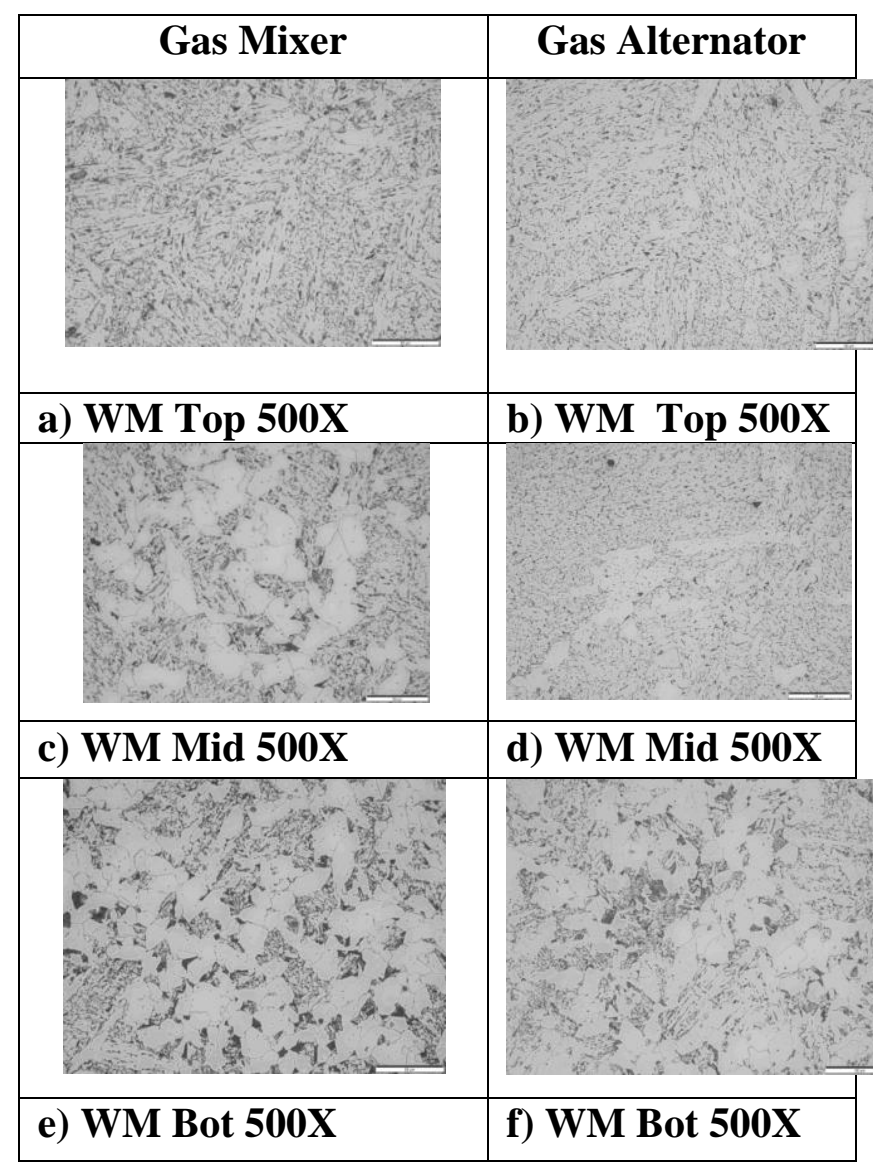

Fig. 18 Microstructure of SA 213 T12 with gas mixer and alternator Weld Metal 


\section{www.rspsciencehub.com}

From Fig. 18, it can be seen that for SA 213 T12, the bainite structure is formed at the weld metal region in both gas mixer and gas alternator The coarse polygonal ferrite was noticed together with bainitic phase at middle and bottom of the weld metal of gas mixer when compared to gas alternator.

The microstructures of the base material, HAZ and weld metal for SA 213 T22 tubes in Fig. 19 to Fig. 21, respectively.

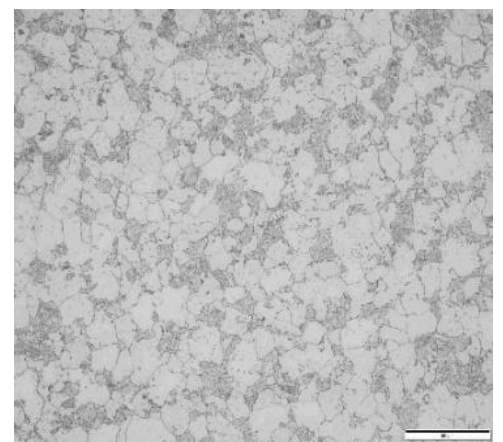

\section{Fig. 19 SA 213 T22 Base metal} microstructure 500X

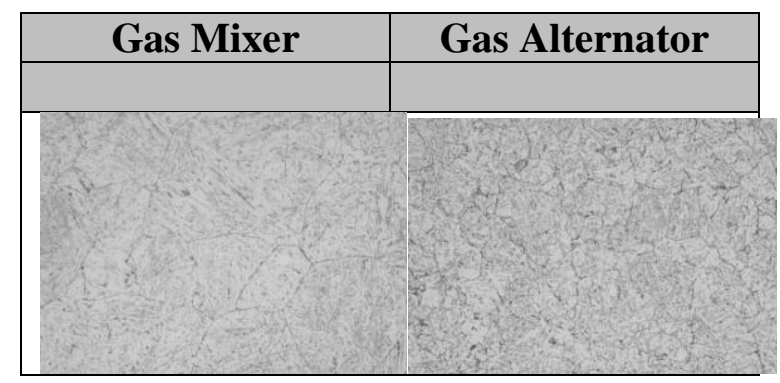

Fig. 20 SA 213 T22 gas mixer and gas alternator HAZ microstructures 500X

The HAZ microstructure of T22 steel Gas Mixerand Gas Alternator in shown in Fig. 20. Prior austenite grain size (PAGS)was finer in gas alternator compared to gas mixer.

The weld metal microstructure of T22 steel Gas Mixer and Gas Alternator in shown in Fig. 21. Bainitic structure was present in the weld metal.In gas mixer the grain or size of bainite formed in the weld metal are coarser. This coarser grain structure result in lesser hardness.

From the microstructures, it can be observed that both weld metal microstructures are found to
Volume 02 Issue 07 July 2020 consist of grain boundary ferrite, acicular ferrite. However, the weld metal deposited by GMAW with alternating gases is found to have relatively more acicular ferrite.

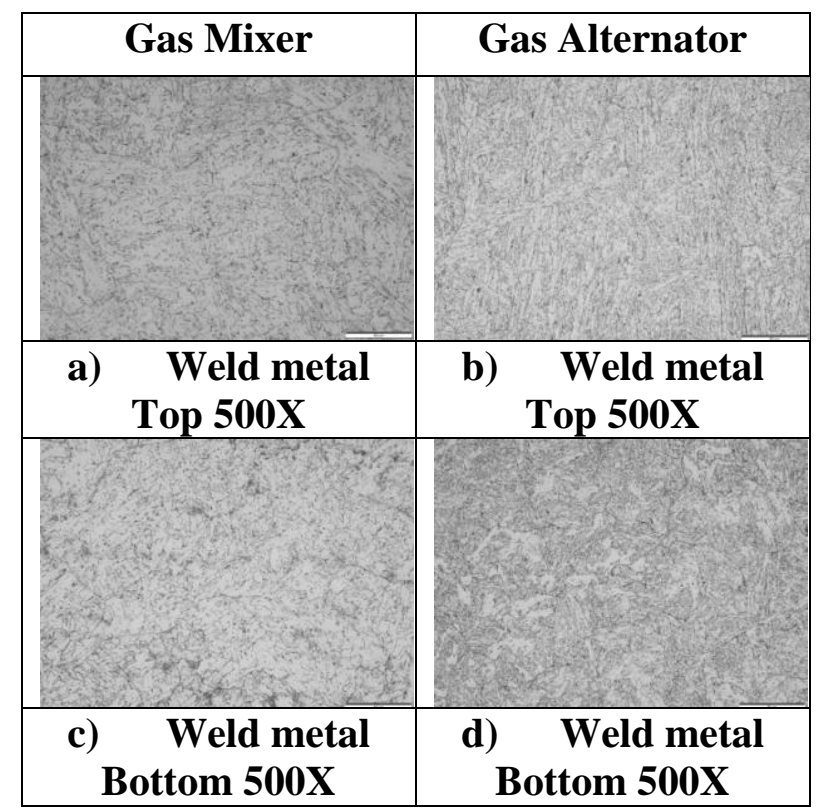

Fig. 21 SA 213 T22 gas mixer and gas alternator weldment microstructures $500 \mathrm{X}$

The weld metal deposited by GMAW with alternating shielding gases of argon and $\mathrm{CO}_{2}$ is also found to contain less amount of non-metallic inclusions compared to the weld metal deposited by GMAW with premixed $80 \%$ Argon $+20 \%$ $\mathrm{CO}_{2}$ shielding gas.

Thus it is evident from the results that the weld metal deposited by GMAW with alternating shielding gases of argon and $\mathrm{CO}_{2}$ provide improved properties as compared to weld metal deposited by GMAW with premixed $80 \%$ Argon $+20 \% \quad \mathrm{CO}_{2}$ shielding gas. The improved mechanical properties can be attributed to the clean weld metal and favourable microstructure brought about by the pulsing effect caused by the alternating shielding gases on the weld pool dynamics.

\section{Conclusion}

From the experimental work carried out with shielding gas from the gas mixer and gas alternator the following can be concluded. 


\section{www.rspsciencehub.com}

- The tensile results of the joints welded using alternator are of equal to that of welding with gas mixer for all the three materials viz. SA 210 Gr C, SA 213 T12 and SA 213 T22.

- The guided bend test results on all these materials show that the ductility and soundness of the welds made with alternator or superior to gas mixer.

- From the Charpy V notch impact tests, it can be concluded that the weld metal deposited with alternating shielding gases GMAW has better toughness properties as compared to the weld metal deposited with gas mixer.

- The heat input is also comparatively less for the welds made with alternating shielding gas and the resultant width of HAZ is also lower comparatively.

- It can also be concluded that the joints with alternator has shown fine acicular microstructure and less inclusions than the joints with gas mixer.

- Gas alternator can replace the gas mixer unit in GMAW process for high temperature and high pressure applications. Since, it is possible to meet the stringent code requirements, it can be implemented in automotive and other sectors also to go green by saving shielding gas consumption.

\section{References}

[1] Young H. Chang, P.E. "Improve GMAW and GTAW with Alternating Shielding Gases". Welding Journal, Feb 2006.

[2] C. Balamurugan, Dr. A. Raja, Dr. K. L. Rohira, Dr. Ashfaq. "Tube butt welding using GMAW with alternating shielding gases". IIW Annual Assembly, 2011

[3] Dr. A. Raja, C. Balamurugan, Dr. K. L. Rohira, Dr. Ashfaq: Investigation into the effect of pulsed gas GMAW on fillet welds. WRI Journal, Vol.29, No.2 2008.
Volume 02 Issue 07 July 2020

[4] George E. Deiter. Mechanical Metallurgy

[5] https://www.mig-welding.co.uk/weldinggas.htm 